\title{
STRATEGIES FOR GLOBALLY RESPONSIBLE EDUCATION MANAGEMENT: A BRAZILIAN CASE STUDY ON EXECUTIVE EDUCATION
}

ESTRATÉGIAS PARA A GESTÃO DE ENSINO GLOBALMENTE RESPONSÁVEL: UM ESTUDO DE CASO BRASILEIRO NA EDUCAÇÃO EXECUTIVA

Submitted: 03/29/2019 - Accepted: 08/10/2019

Double blind peer review Scientific Editor: Patricia Kanashiro DOI 10.13058/raep.2019.v20n3.1485

\section{NORMAN DE PAULA ARRUDA FILHO norman@isaebrasil.com.br}

InStituto Superior de Administração e ECONOMia

\section{MARCIA REGINA MARTELOZO CASSITAS HINO}

Universidade Positivo

\section{BARBARA S. PRZYBYLOWICZ BEUTER}

InSTituto Superior de AdministraçÃo e ECONOMIA

\begin{abstract}
The aim of responsible management education is to build students' capacities to be future sustainable value generators for business and society in general. In this sense, business schools need to promote a sustainable management vision associated with the student's scope of study. Based on this alignment, this research aims to analyze the effectiveness of a sustainability training discipline created by ISAE Brazilian Business School in raising awareness and promoting sustainable management reflection for executive students from different areas of knowledge. Based on the answer of students on questionnaires applied before and after each class, this analyze looks for measure the level of knowledge acquired by the participants, reflecting about this kind of initiative social contribution. The findings demonstrate a significant growth curve in the learning process, representing a positive impact that allows researchers to infer that the "Seminar of Contextualization" indeed has an important contribution to raise awareness among leaders in search of a more sustainable world.

Keywords: Responsible Leadership. Sustainability. Education. SDGs.
\end{abstract}

\section{RESUMO}

O objetivo da educação executiva responsável é capacitar os estudantes para serem futuros geradores de valor sustentável para os negócios e a sociedade em geral. Nesse sentido, as escolas de negócios precisam promover uma visão de gestão sustentável associada ao escopo de estudo do aluno. Com base nesse alinhamento, esta pesquisa tem como objetivo analisar a efetividade de uma disciplina de capacitação em sustentabilidade, criada pelo ISAE Brazilian Business School, na conscientização e promoção de uma reflexão sobre gestão sustentável para estudantes executivos de diferentes áreas do conhecimento. Com base na resposta dos estudantes aos questionários aplicados antes e após cada aula, esta análise procura mensurar o nível de conhecimento adquirido pelos participantes, refletindo sobre a contribuição social este tipo de iniciativa. Os resultados demonstram uma curva de crescimento significativa no processo de aprendizagem, representando um impacto positivo que permite aos pesquisadores inferir que o "Seminário de Contextualização" tem uma contribuição importante para conscientizar os líderes em busca de um mundo mais sustentável.

Palavras-chave: Liderança Responsável. Sustentabilidade. Educação. ODS. 


\section{INTRODUCTION}

Launched in 2015 by the United Nations, the 2030 Agenda for Sustainable Development was a commitment by all nations to review consumption and production processes for a more just and promising future for the planet. With 17 main objectives listed, 169 goals were developed, the SDGs (Sustainable Development Goals) were built in a collaborative way among the countries, considering priority actions to be taken by the year 2030 (UN, 2018).

At the forefront to boost the Agenda is the UN PRME initiative Principles for Responsible Management Education: a global movement of educational institutions in which missionary schools assume the goal of integrating universal values into curricula and research with the purpose of supporting the generation of a more sustainable and inclusive global economy as well as contribute to building more prosperous societies (PRME, 2018). "Higher education has a strong influence in shaping the mental models of many of society's professionals and leaders and is a critical leverage point in creating a sustainable society" (DYER; DYER, 2017). In this sense, the Brazilian business school ISAE (Higher Institute of Business and Economics) reflected on how to disseminate the Agenda 2030 for multidisciplinary students, students of courses in management areas, such as business, law, finance, projects and others.

One of the solution options was the inclusion of an initial short-term discipline to be applied in a customized way to each class. Entitled "Seminar of Contextualization", the discipline aims to introduce students to the concept and world scenario of sustainability, promoting the understanding and reflection of the relevance and need of companies to adopt sustainable management processes. With this in mind, the school seeks to shape conscious, globally responsible and more prepared leaders for the challenges of the contemporary world.

A recent case study in engineering courses identified that the main challenges of insertion of sustainability in courses included; the debate of sustainable issues in a limited extent and only in specific disciplines, the 
difficulty to create a comprehensive teaching of sustainability, the absence of practical and real examples of how sustainability can be embedded in the course context and finally the fact that most activities and examples are focused on environmental issues (RAMPASSO et al, 2019).

Other research done with undergraduate students from a Federal University in Brazil found that their knowledge about sustainability is still overly focused on environmental issues, which would hinder their performance in business management, impacting their ability to consider social and economic aspects in decision-making processes. (SOARES et al. 2017) On the other hand, for Langue et al. (2015), it is through the creation and transfer of knowledge that business schools prepare their students to make responsible decisions. These issues inspired some research questions such as "which HEI (Higher Education Institutes) strategies may be adopted to teach sustainability education?" and "how much of what is taught is absorbed by students?”.

To answer these questions this research aims to analyze the effectiveness of a sustainability training discipline created by ISAE Brazilian Business School in raising awareness and promoting sustainable management reflection for executive students from different areas of knowledge. The evaluation is made through the analysis of the students' learning curve. The data presented here were collected from the answers to questionnaires applied at the beginning and end of each class of the discipline taught in the year 2018.

The research is informative and persuasive in the sense of inspiring other institutions to assume the role of protagonists in the education for sustainability, besides the analytical content of evaluating the effectiveness of the program that is being used as the object of study.

In this regard, the article is structured as follows: an introduction with a presentation of the objective of the research followed by a brief approach to education for sustainability. The methodological procedures are described in the sequence in which the research was operationalized. The contextualization addresses the UN PRME initiative and the Agenda 2030 for Sustainable Development as an inspiration to the discipline "re- 
search object", presented subsequently. The analysis and discussion of the results achieved by the Institution verify the applicability of the discipline in order to understand the contribution of the "Seminar of Contextualization" to society. 


\section{EDUCATION FOR SUSTAINABILITY}

The transformative nature of education was already addressed by Freire (1983) and Delors et al. (2006) even before the discussions on sustainability and sustainable development took place in our society.

Delors et al. (2006) defend the potential of education as a transformation factor by the understanding that teaching does not only include building and accumulating knowledge, but also learning to know, to do, to live together and to be. These four factors were enshrined as "The Four Pillars of Education" by the International Commission on Education for the $21 \mathrm{st}$ Century (DELORS et al., 2006).

"At a time when formal educational systems tend to privilege access to knowledge, to the detriment of other forms of learning, it is necessary to conceive education as a whole. This perspective should, in the future, inspire and guide educational reforms, whether in the elaboration of programs or the definition of new pedagogical policies" (DELORS et al., 2006, p.31-32).

Subsequently, a fifth pillar was added, devoted to learning how to transform oneself and transform society. It recognizes that everyone, acting individually and together, can transform the world since quality education provides the tools for the transformation of society. (ARRUDA FILHO; SANTOS, 2017)

In this sense, Delors et al. (2006) reiterate that one of the main roles reserved for education consists above all in endowing humanity with the capacity to dominate its own development in order to make each person take their destiny in their own hands and contribute to the progress of the society in which they live, basing such development on the responsible participation of individuals and communities.

"By taking on more responsibility in their own development, communities learn to appreciate the role of education as a means of achieving societal goals and, at the same time, as a desirable improvement in the quality of life" (DELORS et al., 2006, p.20). 
On the same line of thought, Freire (1983) criticizes the model of education in which the student only receives information in a passive position of cumulative character. Known as the greatest defender when it comes to the pedagogical practices of a transformative education for the young and adult, Freire defends that the main goal of an institute of education is to prepare its students to be agents of transformation (SANTOS, 2016).

With regard to environmental matters, Freire (2004 apud DICKMANN, 2010) established the concept of Liberating Environmental Education (or Social-Environmental Education) as one which considers social, cultural, economic and political issues, among others. Likewise, Jacobi (2003) argues that Liberating Environmental Education is committed to the construction of critical and emancipated subjects, involved and interested in the transformation of the reality where they are inserted and as citizens aware of their role in the world and in society. In the same way, Achkar (2007) affirms that environmental education is a powerful tool to train citizens committed to the development of collective enterprises based on deep socio-environmental justice criteria.

Therefore, education with a global and systemic vision is an education with the potential to transform the reality that we live in so as to meet the needs of a more just and egalitarian development. This perspective represents the evolution from the concept of Liberating Environmental Education to Education for Sustainability or education for sustainable development since it can be understood as one based on a socially desirable, economically viable and ecologically prudent world (SACHS, 1986).

It was in the environmental movement in the early 1980s that discussions began on education for sustainability at the United Nations. In particular, the Decade of Education for Sustainable Development, established in December 2002 by the General Assembly of the United Nations through Resolution 57/254, covering the years 2005 to 2014 (GADOTTI, 2008). One of that decade's main objectives was to raise the issue of the need to reformulate school curricula in order to integrate sustainable development principles, values, and practices into all aspects of education and teaching (UNESCO, 2005). 
Along these lines, education for sustainable development, according to UNESCO (United Nations Educational, Scientific and Cultural Organization) is the vision of an education that seeks to empower people to take responsibility for creating a responsible future. It aims at improving access to a quality basic education, reorienting education curricula, training and raising public awareness as well as helping people to develop their behaviors, skills, and knowledge they need, now and in the future (UNESCO, 2002).

Despite the discussions of the scientific community on the differences between the terms "education for sustainable development" and "education for sustainability", this article will not focus on analyzing the terms by understanding their complementarities. For the discussion that follows, we will adopt Gadotti's (2008) and Dickman's (2010) vision, that states that sustainability encompasses something far beyond the preservation of natural resources and the viability of a development without aggression to the environment, since it implies a balance of the human beings with themselves and with the planet.

"Therefore, education for sustainability needs to be carefully thought, connected to the complex reality in its multiple dimensions, in order to protect the planet and the quality of life of its inhabitants" (DICKMANN, 2010, 42).

Thus, sustainability education is understood to be interdisciplinary, making use of a variety of pedagogical techniques that promote participatory learning and higher-order thinking skills (UNESCO, 2005). Freire (1983) brought to light the transdisciplinarity issue in education as a construction of a more global and systemic view of the subjects studied.

The Transdisciplinarity Charter adopted at the First International Congress of Transdisciplinarity, which took place at Arrábida Convent, Portugal, in 1994, states that an authentic education should teach to contextualize, concretize and globalize themes, recognizing the existence of different levels of reality, governed by different logics (FREITAS et al., 1994). For Nicolescu (2000), as the prefix "trans" indicates, transdiscipli- 
narity involves a range of disciplines that are, at the same time, mixed between them and beyond each individual one. Its goal is the understanding of the present world, of which one of the imperatives is the overarching unity of knowledge.

To reach this understanding, it is important to incentive students in the development of a systemic vision attentive to issues such as solidarity and responsibility, which for Gadotti (2008) are now requirements for the survival of the planet and the human beings who live in it. Lozano et al. (2015) also emphasize that the integration of sustainable development has become a relevant topic for Higher Education Institutes (HEI) and that some schools took the responsibility to promote the sustainable development principles.

However, for transformation to be effective, schools need to understand that delivery cannot stick to technical and restrictive content, yet it must allow the student to develop a more global and disruptive view. For Senge (1990), learning does not mean reproducing behaviors or memorizing certain contents, but developing the capacity for reflection, understanding, and self-transformation.

Rocha Loures (2004) emphasizes that there is a great urgency in the effort to discover areas that are common to all disciplines and a reorientation of educational approaches in terms of curriculum, content, pedagogy and evaluation is extremely necessary. The author sees this as a weakness of the educational system, to Rocha Loures (2006) "transdisciplinarity would not be an almost insurmountable challenge if our higher education institutions were truly organized to promote it" (ROCHA LOURES, 2004, p.40).

UNESCO itself advocates interdisciplinarity and holism as specific characteristics necessary for sustainability education, understood in the integration of curricula of the disciplines and aligned with values guidance, critical thinking and participatory decision making (ROCHA LOURES, 2004). 


\section{STRATEGIES FOR SUSTAINABILITY EDUCATION}

Education has to be an inspiring way of thinking directed toward sustainability. Although Delors (2006) emphasizes that education cannot be seen as a sole saving strategy, but as a source for understanding the complexity of global phenomena that are underway, Santos (2016) defends that the construction of new bits of knowledge propels the transformations in our daily doings.

At the forefront of the actions required for the ideal of sustainable development, the United Nations works through funds, programs, specialized agencies and initiatives that seek to align this purpose. Specifically, in the area of education, this article brings to light the performance of the PRME (Principles for Responsible Management Education) initiative.

"The PRME is a United Nations-supported initiative founded as a platform to raise the profile of sustainability in schools around the world and to equip today's business students with the understanding and ability to deliver change tomorrow" (PRME, 2018).

Launched in 2007 at the UN Global Compact Leaders Summit in Geneva, Switzerland, PRME's main challenge is to institutionalize responsible executive education, highlighting the strategic role of business schools in this mission.

The institutions that join the PRME take on the commitments to report progress to all stakeholders and share practices related to the six principles described below (HAERTLE et al., 2017):

- Purpose: We will develop the capabilities of students to be future generators of sustainable value for business and society at large and to work for an inclusive and sustainable global economy.

- Values: We will incorporate into our academic activities and curricula the values of global social responsibility as portrayed in international initiatives such as the United Nations Global Compact. 
- Method: We will create educational frameworks, materials, processes, and environments that enable effective learning experiences for responsible leadership.

- Research: We will engage in conceptual and empirical research that shall advance our understanding of the role, dynamics, and impact of corporations in the creation of sustainable social, environmental and economic value.

- Partnership: We will interact with managers of business corporations to extend our knowledge of their challenges in meeting social and environmental responsibilities as well as to explore jointly effective approaches to meeting these challenges.

- Dialogue: We will facilitate and support dialog and debate among educators, students, business, government, consumers, media, civil society organizations and other interested groups and stakeholders on critical issues related to global social responsibility and sustainability.

In the event commemorating the ten years of the initiative, the principle "Values" was revised, incorporating the question of the need to include in the organizational practice the values taught to the students, thereby increasing the degree of commitment and alignment of the signatory institutions.

"With this change, we want to emphasize the importance of our own organizations' practices as role models and to ensure that our own practices are consistent with what we teach and research. This is the first change of the Principles since they were introduced in 2007" (PRME, 2017, p.3).

The same document also confirms an update of the PRME mission, with a view to launching Agenda 2030 for Sustainable Development in 2015. According to the authors,

“(...) together with the six PRME Principles, the SDGs have become the fundament of the PRME initiative and guided our strategic review pro- 
cess in 2016, resulting in an updated mission statement: Realizing the Sustainable Development Goals through responsible management education" (PRME, 2017, p.2).

The Agenda 2030, also known as Sustainable Development Goals (SDGs), consists of a series of 17 objectives and 169 goals focused on solving a wide range of challenges. The topics covered range from the eradication of extreme poverty and hunger to the promotion of health and well-being across the globe, gender equality and quality education for all, urgent concerns regarding water, energy, economic, infrastructure, consumption, climate, our ecosystems and institutions for peace and sustainable development. (PARKES et al., 2017)

Business schools have the responsibility to translate this important global plan into something that impacts their community through stakeholder engagement (WEYBRECHT, 2017). To do so, including the Agenda 2030 in the school curriculum consists of an opportunity within the thinking of sustainability education, in order to promote critical awareness, exchange of ideas, the elaboration of projects and research in this direction. Aleixo et al. (2018) highlight that the engagement of HEIs on sustainability principles has been increased around the world, therefore this study seeks to contribute to the vivid discussions about education on sustainability and teaching approaches.

The next topic presents the institutional context, in order to clarify the position adopted by the institution and its doings as a disseminator of education for sustainability. 


\section{INSTITUTIONAL CONTEXT}

Signatory of the UN Global Compact ${ }^{1}$ initiatives since 2004 and UN PRME - Principles for Responsible Management Education - since 2007, the ISAE business school defined being a protagonist of sustainable development, inspiring globally responsible leaders through a transformative education as its mission. With this, it seeks to inspire students in the adoption of responsible practices that generate economic and socio-environmental development, promoting values, principles, and visions for sustainable global management.

ISAE (Higher Institute of Business and Economics) is a business school inaugurated in 1996 in the city of Curitiba, southern Brazil. Annually, the school has an average of approximately 6,000 students divided into short, medium and long-term courses, such as undergraduate, postgraduate, specialization and professional master's degrees.

The schools' values are; governance, innovation, sustainability, ethics, leadership, and entrepreneurship, applied both in internal management policies and in curriculum and educational practices. Hence, it adopts a hybrid teaching model that aims to unite theory and practice, promoting actions that see beyond the limits of the classroom, acting in accordance with the demands of society (ARRUDA FILHO, 2015).

Inspired by Morin's (2003) ideas on the role of transculturality in teaching, the school created the educational model PerspectivAÇÃO (PerspectivACTION) which consists of a series of extension activities open to each and every student in the institution.

The PerspectivAÇÃO educational model is composed of 14 interdependent activities that together represent a new way of effectuating the education of leaders and managers. This set of activities is divided into four curricular blocks, structured to accommodate multiple learning strategies. Each block, although presenting a differentiated emphasis, is closely related to the others, and together they converge to build a desired output profile: the globally responsible leader (ARRUDA FILHO, 2015).

1 Global Compact is the world's largest corporate sustainability initiative. A call to companies to align strategies and operations with universal principles on human rights, labor, environment and anti-corruption, and take actions that advance societal goals. https: / www.unglobalcompact.org/what-is-gc 
Figure 2 ISAE PerspectivAÇÃO educational model

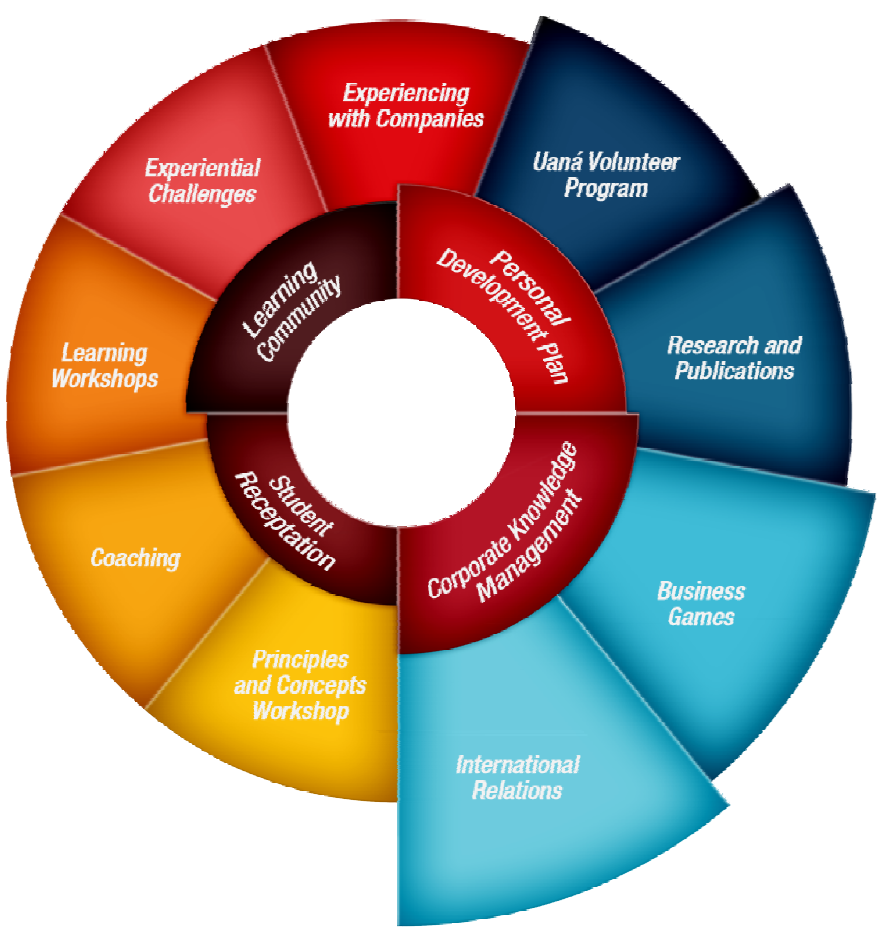

Source: ISAE Institution Files

The aim of PerspectivAÇÃO is to provide students with the opportunity to develop transversal abilities throughout their regular course. Thus, students have access to workshops, technical visits, volunteering programs, coaching sessions and career path development counseling, improving their résumés attributes.

The discipline "Seminar of Contextualization" presented in this study was developed from the union of three activities of the PerspectivAÇÃO educational model: Principles and concepts; Learning community; and Career Legacy. The purpose of the compilation of activities is to prepare students as permanent learners, developing a taste for exchanging experiences, reviewing preconceptions and concepts, proactivity and group learning (ARRUDA FILHO, 2015). 
In view of its commitment to the UN initiatives, from 2015, ISAE adhered to the Agenda 2030 of Sustainable Development and its curriculum, initiating a series of actions to promote the theme among its stakeholders. Among the main activities are:

- The theme became the main focus of the lectures and seminars given by the President of the Institution in various business segments nationally and internationally;

- Organizing large events that mobilized government representatives, UN representatives, members of the private sector and educational institutions to discuss and outline strategies for implementing the Agenda 2030 locally and nationally.

- Internally, carrying out a campaign to disseminate the 17 Sustainable Development Goals, encouraging the mobilization of stakeholders with strong visual communication and training for employees, teachers, students, and suppliers;

- The institution's Sustainability Report was revised in order to identify and report actions that are aligned with SDGs. In 2017, ISAE received a formal PRME recognition for creativity in reporting SDG in the Report;

- The teaching methodology of the Sustainability discipline in the Organizations of the Professional Masters in Governance and Sustainability of ISAE was reformulated so that it had the SDGs as its background. The main objective of the discipline has been to make the students know, understand and become aware of how to identify the SDGs, promoting their implementation within the companies' strategies.

- Incorporation of Agenda 2030 in the syllabus of the first discipline of all courses promoted by ISAE, regardless of the specific area. The discipline in question that receives the name of "Seminar of Contextualization" is the object of study of this research. 


\section{THE SEMINAR OF CONTEXTUALIZATION}

For those who already discuss sustainability, the way the subject permeates society is much more obvious than for those who have a more technical and segmented view. In this way, the appeal with respect to the social responsibility of each individual towards global sustainability needs to be much greater.

For ISAE's students, regardless of the course chosen, besides the technical curriculum, the institution incentives them to participate in an initial discipline that seeks to present the institutional presentation of ISAE based on its guiding concepts, contextualization on Global Leadership, presentation of the principles of the UN Global Compact and PRME initiatives and the Sustainable Development Goals. As this participation is voluntary, the group is not always reached in its entirety.

As ISAE works with short, medium and long-term courses, this initial discipline has a variable timetable of four to twenty-four hours. The main objective of the "Seminar of Contextualization" is to raise students' awareness of sustainable thinking, leading to the adoption of responsible leadership practices. The customization of the discipline takes place according to the profile of the class in view of the specific course area, to be developed in the subsequent meetings.

Table 1 presents the themes and its fundamentals covered in the discipline. The material is updated at each edition. No matter the variation of the class duration, no theme is excluded from the program, with changes only regarding the depth of approach and discussions promoted. The variety of topics addressed in the discipline contradicts Soares et al. (2017) by not including solely environmental themes in the scope of the discipline. 
Table 1 Themes covered at Seminar of Contextualization

\begin{tabular}{|c|c|}
\hline Theme & Scone \\
\hline $\begin{array}{l}\text { Learning } \\
\text { community }\end{array}$ & $\begin{array}{l}\text { The concept promotes a collaborative and sharing learning } \\
\text { environment in which students are incited to collaborate } \\
\text { with the discussions and constructions nurtured in the } \\
\text { classroom. }\end{array}$ \\
\hline $\begin{array}{l}\text { Sustainable } \\
\text { development }\end{array}$ & $\begin{array}{l}\text { Current socio-economic contexts as well as environmental, } \\
\text { political and cultural crises. The idea of a development that } \\
\text { enables better conditions for people and the planet. }\end{array}$ \\
\hline $\begin{array}{l}\text { Sustainability } \\
\text { tripod }\end{array}$ & $\begin{array}{l}\text { Corporate sustainability based on three main axes: } \\
\text { economic development, social justice, and environmental } \\
\text { preservation. }\end{array}$ \\
\hline $\begin{array}{l}\text { Ecological } \\
\text { footprint }\end{array}$ & $\begin{array}{l}\text { The impact of and on man and organizations across the } \\
\text { planet. }\end{array}$ \\
\hline $\begin{array}{l}\text { Systemic } \\
\text { thinking }\end{array}$ & $\begin{array}{l}\text { Encouragement when it comes to the development of a } \\
\text { holistic vision that considers the whole chain impacted by } \\
\text { the choices and attitudes we take within organizations. }\end{array}$ \\
\hline $\begin{array}{l}\text { Global } \\
\text { compact }\end{array}$ & $\begin{array}{l}\text { Historical context, purpose, and principles pertaining to the } \\
\text { Global Compact. }\end{array}$ \\
\hline PRME & $\begin{array}{l}\text { What is and how was built the role of HEIs in the imple- } \\
\text { mentation of the Principles for Responsible Management } \\
\text { Education. }\end{array}$ \\
\hline SDGs & $\begin{array}{l}\text { Presentation of } 17 \text { Sustainable Development Goals and } \\
\text { their } 169 \text { objectives. Historical context, Brazilian and world } \\
\text { performance, main challenges for SDGs, highlighted cases. }\end{array}$ \\
\hline $\begin{array}{l}\text { Globally } \\
\text { responsible } \\
\text { leadership }\end{array}$ & $\begin{array}{l}\text { Characteristics of globally responsible leadership, their } \\
\text { choices, challenges, and consequences. Through the } \\
\text { presentation of inspiring cases, students are encouraged to } \\
\text { take a leading role in promoting change in how they deal } \\
\text { with being leaders. }\end{array}$ \\
\hline $\begin{array}{l}\text { Legacy } \\
\text { concept }\end{array}$ & $\begin{array}{l}\text { Central points that differentiate a career and the construc- } \\
\text { tion of a legacy, once again highlighting the relevance of } \\
\text { individual actions within the context of the social transfor- } \\
\text { mation that the planet needs for sustainable development. }\end{array}$ \\
\hline
\end{tabular}


Classes are planned from a "storytelling" approach created by Booker (2006) which deals with the act of overcoming the "monster". In this strategy, commonly applied in publicity, there is a set of threats and obstacles which must be overcome by a hero with a pioneer posture, equipped with courage and purpose. Therefore, the discourse of the Seminar of Contextualization begins with the presentation of the current situation of the world in the three basic axes of sustainability: social, environmental and economic (ELKINGTON, 2001).

Taking this context into account, we emphasize the characteristics of inspiring leaders that promote the change of the mindset of people and organizations and who have achieved important results, contributing to sustainable development. The purpose here is to inspire by example, by presenting cases and results.

Finally, the classes are intended to induce a call-to-action by encouraging participant engagement and reinforcing each other's role in promoting change regardless of area of expertise and workstream. The idea is to emphasize the importance of systemic thinking so that students can understand the concept of shared responsibility and the impact of their choices on society.

The conduction of the classes follows a dynamic of students' presentations, bringing cases and videos for illustration. The dynamics promote group work and public lectures. There is a strong incentive for self-reflection, self-analysis and the establishment of improvement points focusing on mindset and attitude change.

To ensure unity in the discourse, in the didactics and in the approach of the Seminar of Contextualization, the institution trained a group of teachers who take turns in the application of the discipline according to the internal agenda.

To follow both the teachers' performance and to diagnose the students' understanding of the topics covered in the course, the institution developed a methodology for measuring results. That is, a form composed of a series of questions to be applied at the beginning and end of each "Seminar". 
The form has 10 questions intended to measure students' knowledge about the topics that will be addressed in the discipline. The questionnaire is first applied before the class starts, in the classroom, but before any contextualization about the topics that will be tackled there. The questions are projected on a screen and the students have a few minutes to fill out a numbered form. With each question students have immediate access to the answer, thus assessing their performance. Following, the class starts within the parameters previously mentioned in this research. Before the class ends, students receive another blank form and are reintroduced to the same quiz applied at the beginning of the meeting. Again, they have a few minutes to answer and check on their performance immediately after answering each question, making it possible to create a survey of the learning curve of each student.

Based on the analysis of this curve, this article evaluates the effectiveness of the discipline, contributing to the understanding of this initiative on raising awareness and promoting sustainable management reflection for executive students from different areas of knowledge.

The main challenge reported by the institution for the feasibility of the discipline refers to the fact that since it is not part of the curriculum of the course chosen, the participation of the students in the subject is voluntary, requiring an initial motivation for their adherence. In the same way, the customization of the discipline requires a differentiated dedication of each teacher, in the sense of helping the students to identify with the theme from their area of expertise. This approach makes the discipline unique to each participant as it approaches their reality. 


\section{METHODOLOGY PROCEDURES}

The purpose of research is what should define the methods of analysis. Thus, this research has a quantitative approach, in which the explanation of the phenomenon is given "by collecting numerical data that are analyzed using mathematically based methods (in particular, statistics)" (MUIJS, 2010, p.1). The analysis is focused on the participants' learning curve variation, understanding it as a diagnosis of the strategic maturity acquired in the subject at hand.

The research made use of secondary data to perform an evaluation, contemplating the bibliographic and documentary survey. The documentary survey consisted of three documents: a) Questionnaire on main concepts and principles of sustainability; b) Results of the form that measures the level of knowledge before the exposure in the discipline, and; c) Results of the form that measures the level of knowledge acquired at the end of the discipline.

The Institution ceded the paper versions of a total of 169 measurement forms that determine the level of knowledge acquired by the students, referring to 97 students from seven different classes.

Simultaneous to the reading of the data, the information was includ-

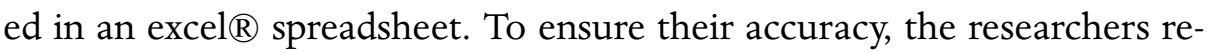
viewed and validated the data included in the worksheet that would be used in the analysis process to certify the accuracy of the information that would be used for analysis.

The research took a quantitative approach. The analysis was performed with a statistical treatment composed of descriptive statistics, using measurements of position and variability, which include mean, frequency, standard deviation, and standard error. The effectiveness of the initiative was analyzed by measuring the variation of the level of knowledge acquired by each student and captured through a questionnaire applied before and after the "Seminar of Contextualization" discipline.

The descriptive analysis through position measures has been gaining space and recognition from society. The use of student test scores has also 
been used to assess teacher performance, and the possibility of using student performance data to uncover main effects, such as school administrators, has attracted government attention (UNTERHALTER, 2019).

The initial descriptive analysis was later enriched with intragroup comparison statistical analyzes, performed by using the T-test for paired or dependent samples (FIELD, 2009). This type of test is appropriate "when observations of the two samples are made on the same individual, for instance, by measuring a characteristic of the individual before and after undergoing treatment” (BUSSAB; MORETTIN, 2013, p. 364).

As part of the preparation of the data for analysis, and considering that the forms, while addressing the same themes, could have different approaches and a disparate number of questions, due to the duration of the discipline in each course, it was necessary to standardize the data so that they could be comparable. The SPSS $\AA$ tool supported the whole statistical analysis process. 


\section{RESULTS AND ANALYSIS}

As a way of approximation and knowledge of the data, Table 2 presents an analysis from the perspective of students, in which it was verified that $37.1 \%$ of respondents were female $(n=36)$ and $62.9 \%$ were male $(n=61)$. Results show that the students were distributed in 6 different classes, where the number of students ranged from 4 to 35 students per class. This variation is explained by applying the form in classes of 2018, including short, medium and long-term courses, as well as courses in the in-company model, so it is common that the number of students can vary widely. Additional to this, the discipline was not obligatory and the students could decide not to participate without prejudice to the course.

The analysis also allowed the identification that $26.8 \%$ of the students answered the form only once and $73.2 \%$ answered the two forms applied. The percentage of completion of the two forms demonstrates that the integration of sustainable development has become a relevant topic not only for Higher Education Institutes but for the students also, expanding the study of Lozano et al. (2015). This is also reinforced due to the fact that the application of the form is the first and last activity of the discipline, so that students who arrive late in class do not respond to the first form, and students who leave before the discipline ends do not respond to the form at the end of the discipline. In both situations, these cases were not considered for analysis purposes, remaining a total of 71 students and 142 forms. 
Table 2 Descriptive Analysis per Student and per Form

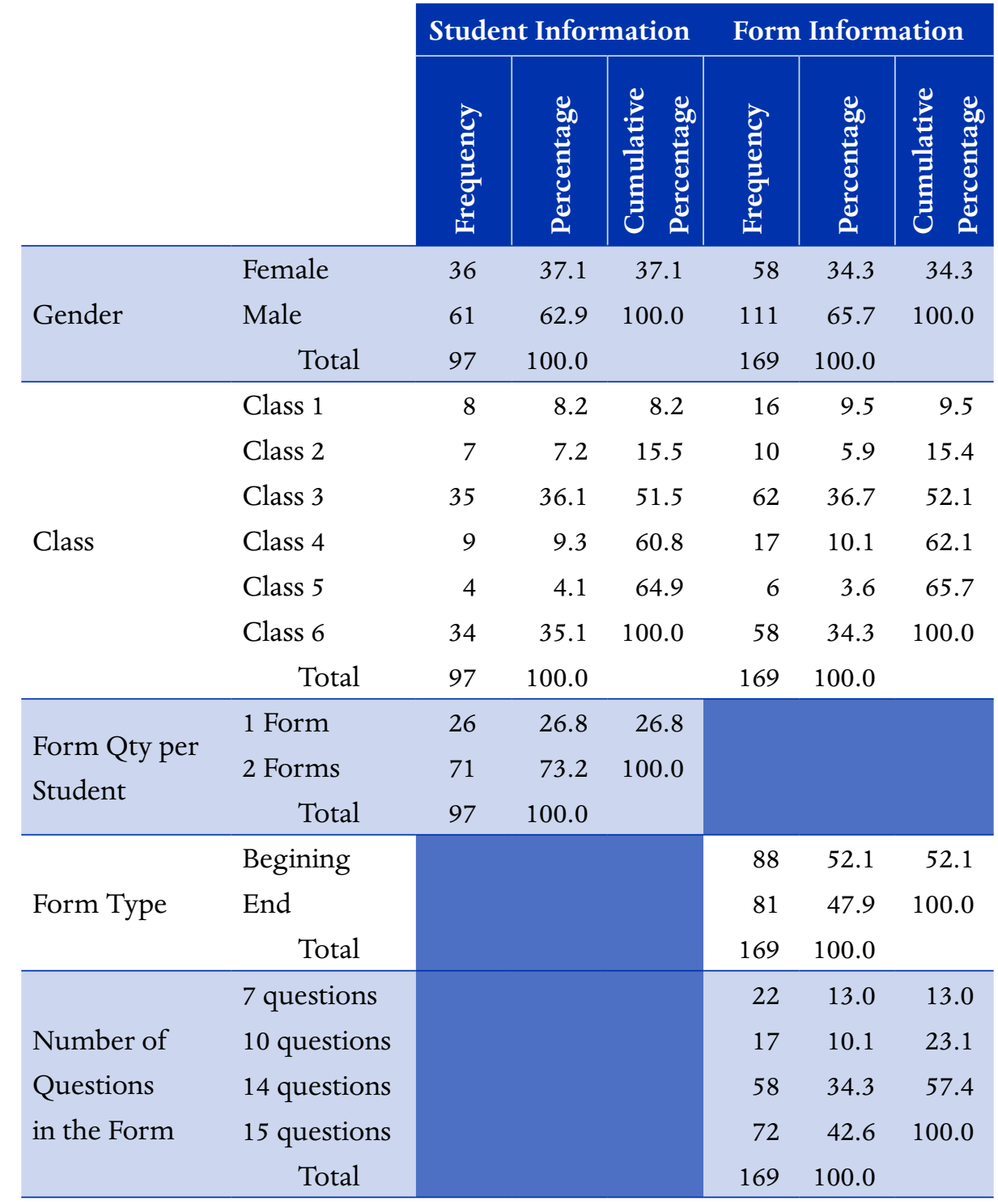

A second analysis was based on the perspective of each completed form, aiming at assessing the level of knowledge before and the one acquired after the discipline. Therefore, the 169 forms $(n=169)$ were again analyzed and organized in Table 2. 
From this perspective, a change in the data was identified, with $34.3 \%$ of the forms being for women $(n=58)$ and $65.7 \%$ for men $(n=111)$. With regards to the classes, the forms are distributed among six classes in which class 1 has 16 forms (9.5\%), class 2 has 10 forms (5.9\%), class 3 has 62 forms (36.7\%), class 4 has 17 forms (10.1\%), class 5 has 6 forms (3.6\%) and class 6 has 58 forms $(34.3 \%)$. Among the forms that were applied, $52.1 \%(\mathrm{n}=88)$ referred to the initial test and $47.9 \%$ referred to the final test $(n=81)$.

The number of questions on the form was also analyzed, as it varies according to the hours of the discipline, which is also defined according to the duration of the discipline where it is being applied. This approach corroborates Rampasso et al (2019) demonstrating how sustainability can be embedded in different course contexts. Forms were developed with 7 to 15 questions. Forms with 7 questions represent $13 \%$ of the total forms analyzed ( $\mathrm{n}=22)$, the 10 questions represent $10.1 \%(\mathrm{n}=17)$, the 14 questions are responsible for $34.3 \%(\mathrm{n}=58)$ and the 15 questions represent $42.6 \%(\mathrm{n}$ $=72$ ) of the total of forms analyzed.

As a result of the use of forms with different amounts of questions, it was necessary to transform the volume of hits to the percentage of hits so that the data could be comparable. The following calculation formula was used:

$$
\text { HitPercentage }=\frac{\text { HitPercentage }}{\text { NumberofQuestionsintheForm }}
$$

Table 3 presents a compilation of the analysis data regarding the effectiveness of the discipline, which identified a significant variation between the average of correct answers in the questionnaires applied before and after the discipline. While the initial average found before the discipline presents a total of $0.569 \%$ hits, after the discipline, there is an evolution to $0.904 \%$ correct answers, representing an increase of 33 percentage points.

When evaluating the median, that is, the variation where most hits are, the data also show that, among the study participants, the concentra- 
tion of correctness in the initial form was 0.571 , while after the class the concentration of knowledge changed to 0.933 .

Table 3 Effectiveness Analysis

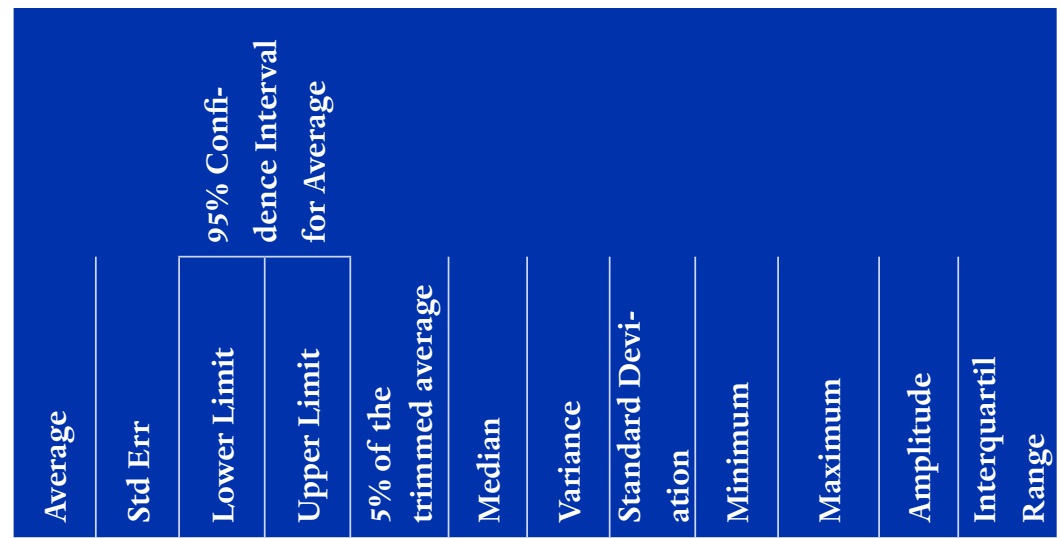

Form

Begining

$\begin{array}{llllllllllll}.569 & .018 & .532 & .606 & .572 & .571 & .030 & .173 & .143 & 1.000 & .857 & .263\end{array}$

\section{Form}

End

$\begin{array}{llllllllllll}.904 & .012 & .880 & .929 & .916 & .933 & .012 & .110 & .571 & 1.000 & .429 & .143\end{array}$

The analysis in a graphical way (Graphic 1) makes the amplitude of certain answers of the initial form evident, varying from 0.143 to 0.571 in the final form. The chart also shows that the minimum level of knowledge of all participants after the discipline equals almost $75 \%$ of the initial form's level of accuracy. The graphic shows three answers that are not aligned with the others, being considered outliers, that is, out of the group response standard. They are represented in the graphic by the three isolated points.

A more in-depth assessment related to the duration of the discipline reflected in the number of questions in the form applied before and after, suggests that, regardless of the duration of the discipline, the content can be fully assimilated by the participants (Graphic 2). 
Graphic 1 Boxplot by Form Type

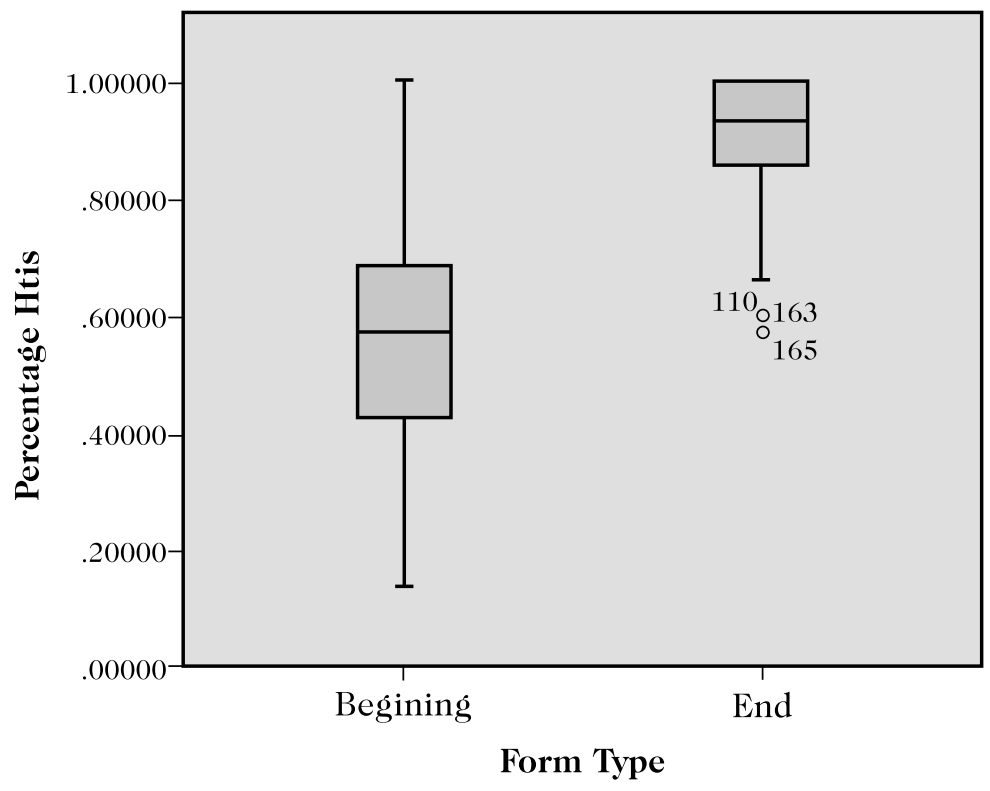

Graphic 2 Boxplot by Number of Questions per Form

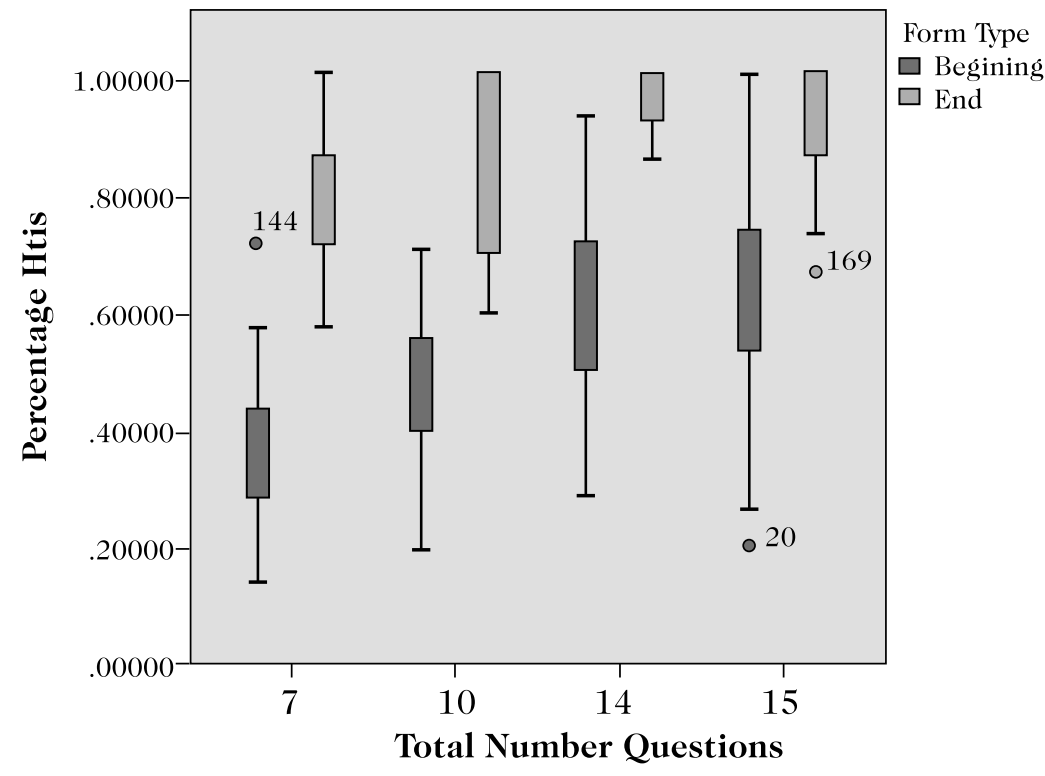


However, the data demonstrates that the most effective knowledge is acquired from the medium - represented by the ten-question form - and long duration discipline - represented by the fourteen and fifteen question forms. All of these subjects have a $100 \%$ accuracy concentration in the final forms, regardless of their duration. These results strengthen Senge (1990), since it is understood that if students are given more time devoted to reflection, understanding, and self-transformation, better results end up taking place.

The graphics presented are intended to visually represent the data found and to verify the significant evolution of the knowledge acquired among the participants of the discipline. Thus, the researchers sought to identify both the institution students' level of general knowledge regarding themes related to sustainability and the importance of strategies in order to broaden the knowledge of society in this sense.

The analysis based on the use of the T-test allowed to evaluate the students' individual performance while considering the results of the form before and after their participation in the Seminar of Contextualization. This analysis differs from previous tests because it considers only student forms that completed the initial and final versions, that is, completed the questionnaire before and after the course.

On average, participating students show greater knowledge after the contextualization discipline $(\mathrm{M}=0.9191$, standard error $=0.01163)$ than before the beginning of the discipline $(M=0.5633$, standard error $=0.02160$, $\mathrm{t}(72)=-19.133,(\mathrm{p}=0.001, \mathrm{r}=0.92)$. Besides being statistically significant, the effect is also considerable $(\mathrm{r}=0.92)$. In line with Langue et al. (2015) study, the results attest to the transfer of knowledge conveyed by business schools, preparing the students to make responsible decisions. 


\section{FINAL CONSIDERATIONS}

This article proposes to present a case study on the creation of a sustainability discipline, applied transversally in a Brazilian business school, in order to promote a vision of sustainable management among new and future leaderships.

From the analysis of the evolution of the learning acquired by the evaluated students, it becomes evident the effectiveness of the applied methodology and, consequently, its role of prominence in the process of sensitization of the leaderships in search of a more sustainable world.

Although nearly five years have passed since the end of UNESCO's established Decade of Education for Sustainable Development, it is believed that much remains to be done to guide education institutions to adopt education for sustainability across different curricula.

Amongst the existing movements, this article highlights the UN PRME - Principles for Responsible Management Education initiative, in view of the support from the United Nations and its governance structure, which lists principles to be followed and advocates a reporting policy to monitor actions carried out by the signatory schools.

In this sense, the case presented in this study aims to serve as an example and inspiration for other HEI in the development of strategies that combat the unilaterality of sustainability and promote transculturality in education, addressing the three axes of sustainability with the same weight of importance, incorporating such context into the courses of different areas of knowledge. A differential of the Seminar of Contextualization is that it encourages the integration of the class and seeks to sensitize students to the importance of developing new behavioral skills necessary to meet the challenges of economic, social and environmental sustainability. In addressing the principles of the UN, Global Pact and PRME initiatives, it highlights the purpose of the school and the expectation of engaging students as a community.

For the authors presented in this research, effective education presupposes a transformation of thinking in which the student changes his/ 
her passive posture to adopt a protagonist profile of his/her learning. This line of thought within the context of education for sustainability presupposes the valorization of the vision of development on a sustainable basis and aimed at building a more just and egalitarian future.

By analyzing the learning curve of participants in the Seminar of Contextualization, after the discussions on Global Leadership, the principles of the UN Global Compact and PRME initiatives and the Agenda 2030 for Sustainable Development, it was possible to see an evolution in the students' knowledge, suggesting a greater involvement of the participants with the theme.

The school has a social role that goes beyond its physical limits, in this line, the case presented is an important example of acting, protagonism and practical application of PRME's global principles of which the institution is a signatory. The social contribution of this type of initiative is characterized by the impact that the decisions of these HEI leaders have on society. Preparing a student to be a globally responsible leader goes beyond teaching technical skills, it also must encompass an investment in the transformative potential of education.

As a limitation of the research, the analysis applied here was limited to evaluating the initial and final data of the applied questionnaire. It is understood that an evaluation from the perspective of each one of the questions of the subject's questionnaire is still possible, allowing for a better evaluation of the degree of learning by topic.

Future research suggests a more detailed analysis considering the practical changes adopted and applied by the students in different segments of the market, in order to attest the relevance of the discipline in what pertains to the initiatives in favor of education for sustainability and the role of the school as a transforming agent of reality. Another opportunity for future studies is the analysis of topics discussed in the classroom, allowing to verify the need for greater and/or less dedication to each theme, in its process of awareness for future transformation. 


\section{REFERENCES}

ACHKAR, Marcel; DOMÍNGUEZ, Ana; PESCE, Fernando. Educación ambiental: una demanda del mundo hoy. Educación Ambiental, 2007.

ALEIXO, Ana Marta; LEAL, Susana; AZEITEIRO, Ulisses Miranda. Conceptualization of sustainable higher education institutions, roles, barriers, and challenges for sustainability: An exploratory study in Portugal. Journal of Cleaner Production, v. 172, p. 1664-1673, 2018. DOI: http://dx.doi.org/10.1016/j.jclepro.2016.11.010

ARRUDA FILHO, Norman. Perspectivaction: A new educational framework to include sustainability in responsible management education. In: Transformative approaches to sustainable development at universities. Springer, Cham, 2015. p. 257-270. DOI: http:/ / dx.doi. org/10.1007/978-3-319-08837-2_18.2015

ARRUDA FILHO, Norman; DOS SANTOS, Antonio R. ISAE e Sistema Ocepar: parceria para educação transformadora. PR Coop. Tecn. Cient., Curitiba, v. 12, ed. Esp. 14, p. 40-69, 2016.

BOOKER, Christopher. The seven basic plots: Why we tell stories. Continuum, 2006.

BUSSAB, Wilton de O.; MORETTIN, Pedro A. Estatística básica. 5a edição. Editora Saraiva, 2013.

DE LANGE, Deborah E. How do universities make progress? Stakeholder-related mechanisms affecting adoption of sustainability in university curricula. Journal of Business Ethics, v. 118, n. 1, p. 103-116, 2013. DOI: https:/ / doi.org/10.1007/s10551-012-1577-y

DELORS, Jacques; et al. Educação: um tesouro a descobrir. 10. ed. São Paulo: Cortez, 2006.

DICKMANN, Ivo. Contribuições do pensamento pedagógico de Paulo Freire para a educação socioambiental a partir da obra pedagogia da autonomia. Produção de terceiros sobre Paulo Freire; Série Dissertações, 2010.

DYER, Georges; DYER, Michelle. Strategic leadership for sustainability by higher education: the American College \& University Presidents' Climate Commitment. Journal of Cleaner Production, v. 140, p. 111-116, 2017. DOI: http:/ / dx.doi.org/10.1016/j.jclepro.2015.08.077

ELKINGTON, John. Canibais com garfo e faca. São Paulo: Makron Books, 2001.

FIELD, Andy. Descobrindo a estatística usando o SPSS. Bookman Editora, 2009.

FIGUEIRÓ, Paola Schmitt; RAUFFLET, Emmanuel. Sustainability in higher education: a systematic review with focus on management education. Journal of cleaner production, v. 106, p. 22-33, 2015. DOI: http:// dx.doi.org/10.1016/j.jclepro.2015.04.118

FREIRE, Paulo. Pedagogia do oprimido, 13a., ed. Rio de Janeiro: Paz e Terra -Coleção O Mundo Hoje, 1983. 
FREITAS, Lima de; MORIN, Edgar; NICOLESCU, Barasab., "Carta da Transdisciplinaridade”, 1994, Educação e transdisciplinaridade. Guarujá, SP, Brasil, UNESCO, v.1, 2000.

GADOTTI, Moacir. Educar para a Sustentabilidade: uma contribuição à Década da Educação para o Desenvolvimento Sustentável. São Paulo: Editora e Livraria Instituto Paulo Freire, 2008.

HEARTLE, Jonas; PARKES, Carole; MURRAY, Alan., HAYES, Ross. PRME: Building a global movement on responsible management education. The International Journal of Management Education. v. 15 n 2 Part B p. 66-72, 2017. DOI: https:// doi.org/10.1016/j. ijme.2017.05.002

JACOBI, Pedro. Educação Ambiental, Cidadania e Sustentabilidade. Cadernos de Pesquisa, n. 118, p. 189/205, março, 2003.

LOZANO, Rodrigo et al. A review of commitment and implementation of sustainable development in higher education: results from a worldwide survey. Journal of Cleaner Production, v. 108, p. 1-18, 2015. DOI: https:// doi.org/10.1016/j.jclepro.2014.09.048

MUIJS, Daniel. Doing quantitative research in education with SPSS. Sage, 2010.

NICOLESCU, Basarab et al. Um novo tipo de conhecimento: transdisciplinaridade. Educação e transdisciplinaridade, v. 1, 2000.

PARKES, Carole; et al. The Principles for Responsible Management Education (PRME): the first decade - What have been achieved? The next decade - Responsible Management Education's challenge for the Sustainable Development Goals (SDGs) The International Journal of Management Education, v. 15, $\mathrm{n}^{\circ}$ 2, Part B, p. 61-65, 2017. DOI: https:/ / doi.org/10.1016/j.ijme.2017.05.002

PRME - Principles for Responsible Management Education. Making global goals local business: Bringing the SDGs to Every Classroom and Every Organization. Outcomes Declaration 2017. Available at http://www.unprme.org/resource-docs/2017OutcomeDeclaration.pdf Access in $26^{\text {th }}$ September 2018.

PRME - Principles for Responsible Management Education. Available at http:/ / www.unprme. org / participation/index.php. Accessed in $26^{\text {th }}$ September 2018.

RAMPASSO, I. S. et al. Some of the challenges in implementing Education for Sustainable Development: perspectives from Brazilian engineering students. International Journal of Sustainable Development \& World Ecology, p. 1-10, 2019. DOI: https:/ / doi.org/10.1080/135 04509.2019.1570981

ROCHA LOURES, Rodrigo C. da. Educar e inovar na sustentabilidade. Curitiba: UNINDUS, 2008.

SACHS, Ignacy. Ecodesenvolvimento: crescer sem destruir. São Paulo: Vértice, 1986.

SANTOS, Wendel Souza. Andragogia e a educação de idosos, jovens e adultos. Alumni, v. 4, n. 7, p. 38-47, 2016. 
SENGE, Peter M. A quinta disciplina: arte e prática da organização de aprendizagem. São Paulo: Best Seller, 1990.

SOARES, Willon Henrique Sousa; ABDALA, Etienne Cardoso; CEZARINO, Luciana Oranges. Engajamento e conhecimento de estudantes sobre sustentabilidade à luz dos princípios do PRME. Engema, São Paulo, Brasil, 2017.

UN - United Nations. About the Sustainable Development Goals. Available at https: / www. un.org/sustainabledevelopment/sustainable-development-goals/ Accessed in 09 October 2018.

UNTERHALTER, Elaine. The Many Meanings of Quality Education: Politics of Targets and Indicators in SDG 4. Global Policy, v. 10, p. 39-51, 2019.

UNESCO - Organização das Nações Unidas para a Educação, a Ciência e a Cultura. Education for sustainability - from Rio do Johannesburg: Lessons Learnt from a Decade of Commitment, 2002.

UNESCO - Organização das Nações Unidas para a Educação, a Ciência e a Cultura. International Implementation Scheme, 2005.

WEYBRECHT, Giselle. From Challenge to Opportunity - Management education's crucial role in sustainability and the Sustainable Development Goals - An overview and framework. The International Journal of Management Education. Vol. $15 \mathrm{~N}^{\circ} 2$ Part B pp. 8492, 2017. DOI: https:// doi.org/10.1016/j.ijme.2017.02.008 


\section{ABOUT THE AUTHORS}

\section{NORMAN DE PAULA ARRUDA FILHO norman@isaebrasil.com.br}

$\mathrm{PhD}$ in Administration - ISCTE-Instituto Universitário de Lisboa

Institutional bond: Instituto Superior de Administração e Economia

Curitiba/PR - Brazil

Area of interest in research: Education, Sustentability, Sustainable Development

Rua Visconde de Guarapuava, 2943 Centro Curitiba/PR 80010-100

\section{MARCIA REGINA MARTELOZO CASSITAS HINO marciahino@uol.com.br} $\mathrm{PhD}$ in Administration - EAESP-FGV

Institutional bond: Universidade Positivo

Curitiba/PR - Brazil

Area of interest in research: Education, Technology, Sociotechnical transition, Sustainability.

BARBARA S.PRZYBYLOWICZ BEUTER barbara.beuter@isaebrasil.com.br Master student in Governance and Sustainability - ISAE

Institutional bond: Instituto Superior de Administração e Economia Curitiba/PR - Brazil

Area of interest in research: Education, Sustainability, Sustainable Development. 